\title{
NEFH wt Allele
}

National Cancer Institute

\section{Source}

National Cancer Institute. NEFH wt Allele. NCI Thesaurus. Code C88039.

Human NEFH wild-type allele is located in the vicinity of $22 \mathrm{q} 12.2$ and is approximately 11 $\mathrm{kb}$ in length. This allele, which encodes neurofilament heavy polypeptide protein, is involved in the modulation of the structure of neuronal processes. Mutations in the gene are associated with greater susceptibility to amyotrophic lateral sclerosis. 